\title{
Kerangka Konseptual Integritas: Studi Eksplorasi pada Guru-guru Sekolah Dasar di Yogyakarta
}

\author{
Ika Widyarini $^{(1)}$, Kwartarini W. Yuniarti(2), Leo A. Nugraha ${ }^{(2)}$ \\ ika_widyarini@ub.ac.id \\ (1)Jurusan Psikologi, Universitas Brawijaya, Malang \\ ${ }^{(2)}$ Fakultas Psikologi, Universitas Gadjah Mada, Yogyakarta
}

\begin{abstract}
Integrity is commitment to positive values i.e. honesty, trust, fairness, respect, responsibility and courage. To encourage children to commit to such positive values, elementary school educatorsare expected to understand the essential values of integrity. This study is an exploratory qualitative study attemptingto buildan understanding on the Indonesian school teacher's concepts ofintegritywith an indigenous approach. An open ended survey was conducted to a sample of 121 elementary school teachers from Kabupaten Sleman Yogyakarta. A group of elementary school teachers from the sample was recruited to assist the data analysis process, to ensure a data coding in accordance to their conception. The categories were analyzed by descriptive statistics. The result of this research revealed the perspective of elementary school teachers on the importance of certain values involved in integrity, how they teach their students to embrace the values. Theoretical and applied implementation of this research results is discussed.
\end{abstract}

Keywords: integrity; indigenous approach; values

\begin{abstract}
Integritas adalah komitmen terhadap nilai-nilai positif yaitu kejujuran, kepercayaan, keadilan, rasa hormat, tanggung jawab dan keberanian. Untuk mendorong siswa SD berkomitmen pada nilai-nilai positif seperti itu, pendidik sekolah dasar diharapkan memahami nilai-nilai penting dari integritas. Penelitian ini merupakan studi kualitatif eksploratif yang mencoba membangun pemahaman tentang konsep integritas guru sekolah Indonesia dengan pendekatan indijenous. Survei open-ended disebarkan dan diisi 121 guru sekolah dasar dari Kabupaten Sleman Yogyakarta. Kemudian sekelompok guru sekolah dasar dari partisipan tersebut direkrut untuk membantu proses analisis data, untuk memastikan pengkodean data sesuai dengan konsepsi mereka. Kategori dianalisis dengan statistik deskriptif. Hasil penelitian ini mengungkapkan perspektif guru sekolah dasar tentang pentingnya nilai-nilai tertentu yang terlibat dalam integritas dan bagaimana mereka mengajar siswa mereka untuk mengadopsi nilai-nilai luhur. Penerapan teoritis dan praktis dari hasil penelitian ini akan dibahas.
\end{abstract}

Kata kunci: integritas; pendekatan indijenous; nilai-nilai

Received: October 25, 2018 Accepted: April 24, 2019

How to cite: Widyarini, I., Yuniarti, K. W., \& Nugraha, L. A. (2019). Kerangka Konseptual Integritas: Studi Eksplorasi pada Guru-guru Sekolah Dasar di

Yogyakarta. MEDIAPSI, 5(1), 16-29. doi: https://doi.org/10.21776/ub.mps.2019.005.01.2

\section{Pendahuluan}

Seorang manusia harus teguh pada keyakinannya, memahami nilai-nilai dan prioritasnya untuk berperilaku atau memilih keputusan paling benar di dunia yang terus berubah. Perilaku yang benar pada akhirnya akan mempengaruhi kesejahteraan, kelangsungan hidup, dan titik tolaknya selanjutnya akan kelangsungan nilai-nilai luhur dalam kehidupan manusia. Pedoman utama untuk melewati dunia yang terus berubah adalah integritas. Integritas kata yang berasal dari bahasa Latin integritas, yang berarti keutuhan, kesehatan, tidak tersentuh, utuh, dan menyeluruh. Kamus Besar Bahasa 
Indonesia (http://kbbi.web.id/integritas) mendefinisikan integritas sebagai "kualitas, sifat, atau keadaan yang memungkinkan orang-orang yang memiliki kemampuan dan kemampuan yang memancarkan kewibawaan; kejujuran".

Pandangan lain menyebut integritas sebagai kepribadian terintegrasi, Stanford's Encyclopedia of Philosophy (2013) menyatakan bahwa integritas adalah upaya orang-orang yang mengintegrasikan berbagai bagian dari kepribadian mereka ke dalam keutuhan yang harmonis. Itu berarti integritas orang sejajar dengan integritas masalah, upaya untuk menjaga diri utuh dan tidak rusak. Seseorang yang berintegritas juga memiliki kesadaran akan setiap bagian diri yang terkait dan memiliki konsistensi dari bagian diri yang terkait.

Persepektif yang berbeda menganggap integritas sebagai kesediaan untuk menerima konsekuensi dari prinsipnya, ketika usaha untuk mempertahankan prinsip-prinsip itu sulit dan meskipun konsekuensinya tidak menyenangkan (McFall, 1987). Calhoun (1995) berpendapat bahwa integritas adalah kebajikan sosial sebagai pertimbangan yang tepat dari penilaian terbaik individu dan bahwa orang yang berintegritas akan teguh memegang nilai-nilai dalam komunitas dan mencoba untuk menemukan apa yang dalam hidup ini layak dilakukan.

Integritas juga dipandang sebagai tujuan moral. Ashford (2000) menyatakan bahwa orang-orang yang berintegritas memiliki pemahaman yang kuat tentang kewajiban moral mereka, mereka tidak memiliki kesalahan secara moral. Halfon (1989) menekankan tujuan moral integritas dalam diri seseorang akan mendorong individu untuk secara konseptualsudah jelas, secara logis telah konsisten, selalu mengklarifikasi bukti empiris yang relevan dan berhati-hati dalam mempertimbangkan isu-isu moral.

Scherkoske (2010) menyatakan bahwa integritas adalah suatu kebajikan, memotivasi seseorang untuk menemukan kebenaran, keyakinan yang paling dibenarkan dan mengejar kemungkinan baru untuk menghadapi kebenaran. Jadi integritas bukanlah masalah dalam status quo, tetapi ini adalah pencarian kebenaran yang terus menerus di dalam. Integritas akan membutuhkan pemeriksaan diri yang sangat sukses yang melibatkan pemeriksaan emosi moral atau emosi penilaian diri yaitu penyesalan, penyesalan, rasa bersalah, rasa malu. Emosi moral semacam itu mungkin penting untuk integritas seperti yang diyakini oleh Pugmire (2005).

Integritas sebagai subjek telah diakui sebagai salah satu konstruksi dalam psikologi positif (Cameron, 2003; Park \& Peterson, 2003; Peterson \& Seligman, 2004; Schabracq, 2003). Definisi integritas kemudian disarankan oleh Peterson \& Seligman (2004) hendaknya diungkapkan dalam kriteria perilaku yang konsisten dengan konstruksi lain dalam psikologi positif:

- Pola perilaku yang teratur yang konsisten dengan nilai-nilai yang dianut, perbuatan dan kata-kata konsisten;

- Pembenaran umum atas keyakinan moral, bahkan jika keyakinan itu tidak populer;

- Memperlakukan orang lain dengan hatihati, terbukti dengan membantu mereka yang membutuhkan, atau dapat diartikan juga sebagai kepekaan terhadap kebutuhan orang lain.

Mempromosikan integritas dewasa ini sangat penting karena integritas adalah sudut 
pandang yang kuat untuk bertahan dalam perubahan jaman, melawan korupsi dan berbagai pengaruh perilaku buruk lain. Saat ini Indonesia masih berada di ranking memprihatinkan dalam transparansi atau kebersihan sistem dibanding negara lain (ranking 96 dari 180). Skor Corruption Perception Index Indonesia adalah 37 dari skor maksimal 100 (Transparency International, 2018) yang mencerminkan praktik tindakan transparan atau jujur bertanggung jawab dalam pengelolaan negara ini masih jauh dari baik. Corruption Perception Index (Transparency International, 2018) adalah salah satu tolok ukur untuk menilai apakah suatu negara memiliki konsistensi dalam menegakkan integritas.

Di bagian lain dunia, integritas telah banyak dibahas dalam psikologi sebagai karakteristik yang diperlukan dari seorang pemimpin yang utama (Kaiser \& Hogan, 2010; Craig \& Gustafson, 1998; Petrick \& Quinn, 1997) atau karyawan (Becker, 1998; Harter, 2002; Schabracq, 2003; Trevino, Hartman \& Brown, 2000) untuk mencapai kinerja perilaku optimal di tempat kerja (Ones, Viswesvaran \& Schmidt, 1993). Di Indonesia integritas juga sering disebut sebagai kunci sukses mengelola negara, memimpin lembaga-lembaga serta dalam mendidik kaum muda. Namun, penelitian integritas dalam pengaturan pendidikan usia dini sangat terbatas. Untuk alasan itu, penelitian eksplorasi tentang masalah integritas sangat diperlukan.

Integritas dalam bidang pendidikan di Indonesia juga masih sangat lemah, Kasus plagiarisme di pendidikan tinggi Indonesia saat ini masih memprihatinkan. Jeffrey Winters, guru besar ilmu politik dari Northwestern Unversity yang juga Ketua Dewan Pengawas Indonesian Scholarship and
Research Support (ISRSF), mengemukakan bahwa ditemukan plagiarisme dalam $25 \%$ esai akademik mahasiswa Indonesia(Tarigan, 2016). Menurut data Kemendikbud, kasus plagiasi pada proses sertifikasi dosen mencapai 808 kasus di tahun2013 saja (Gunawan, 2014). Selain dilakukan oleh berbagai golongan civitas akademik, kasuskasus plagiasi ini terjadi di berbagai institusi pendidikan tinggi Indonesia (Hakim, 2014; Wirawan, 2017; Wiwoho \& Gumilang, 2017) maupun lembaga penelitian (LIPI, 2006). Hal ini menunjukkan bahwa integritas harus mulai ditanamkan dengan serius sejak pendidikan usia dini.

Pendidikan di sekolah dasar, bersama dengan keluarga dan masyarakat, adalah fondasi penting untuk pengembangan integritas. Penelitian integritas di bidang pendidikan sebagian besar dilakukan dalam pendidikan tinggi mengenai integritas akademik dalam penelitian atau penulisan publikasi ilmiah. Masih sangat terbatas penelitian integritas diperiksa dari perspektif guru pendidikan awal yaitu guru sekolah dasar. Guru sekolah dasar harus mengajar siswa mereka pemahaman dasar prinsip-prinsip moral dan kebajikan sebagai dasar integritas. Selain itu, di Indonesia konsep integritas sering ditentukan sebagai karakteristik sumber daya manusia yang ideal yang bekerja untuk lembaga pendidikan. Oleh karena itu, penting untuk mempelajari persepsi pendidik, terutama guru sekolah dasar di Indonesia tentang integritas. Pertanyaan penelitian akan berusaha menjawab:

1. Apa arti dari integritas?

2. Aspek apa yang terkait dengan integritas?

3. Apa peran guru sekolah dasar dalam 
pengembangan integritas?

Tujuan dari penelitian ini adalah untuk mengeksplorasi konsepsi integritas dan aspekaspek utama yang terkait dengan integritas di antara guru sekolah dasar di Indonesia. Oleh karena itu, tujuan dari makalah ini adalah untuk membangun kerangka konseptual yang dapat menawarkan pemahaman yang lebih baik tentang integritas dalam perspektif Indonesia, khususnya di kalangan guru sekolah dasar.Penelitian ini juga berusaha memahami konstruk integritas yang mendasar untuk pengembangan teori lebih lanjut. Implikasi praktis dari temuan ini akan dibahas untuk peningkatan integritas di Indonesia.

\section{Metode}

\section{Desain penelitian}

Penelitian ini menerapkan pendekatan psikologi indijenous, dengan merekrut analis data secara budaya dalam jarak yang dekat dengan peserta penelitian untuk mengodekan tanggapan agar tidak memiliki kesenjangan persepsi. Data dianalisis menggunakan metode kualitatif dan kuantitatif secara bersamaan. Barret (2003) menyatakan bahwa ketergantungan semata dalam penstrukturan kuantitatif suatu variabel psikologis dapat membatasi pengetahuan dan klaim yang menghasilkan teori yang dapat dibuat. Secara implisit, pendekatan kualitatif adalah memahami integritas sebagai konstruk psikologis dalam perspektif bahasa Indonesia. Oleh karena itu, pendekatan penelitian kualitatif dianggap paling efisien dalam menyelesaikan tujuan penelitian sebelumnya. Penelitian kualitatif memberikan akses dan pemahaman pada orang-orang yang mengalami pengalaman subjektif dari fenomena psikologis (Camic, Rhodes \& Yardley, 2003), seperti integritas.

\section{Partisipan}

Sebanyak 121 guru sekolah dasar di wilayah Sleman di Daerah Istimewa Yogyakarta (29 laki-laki; 24\% dan 92 perempuan; 76\%)

\section{Pengumpulan data}

Data diperoleh melalui kuesioner terbuka tentang integritas. Kuesioner terbuka telah didistribusikan di antara peserta yang harus menjawab 5 pertanyaan tentang integritas.

\section{Analisis data}

Analisis data menggunakan kombinasi metode kualitatif dan kuantitatif. Pada tahap pertama, analisis data pada tahap kategori luas dilakukan oleh tiga guru SD yang telah mengisi kuesioner sebagai subyek penelitian. Analisis data oleh subjek awalnya direncanakan untuk memastikan kedekatan kategori dengan tanggapan asli mereka. Namun, kategori yang dihasilkan dari analisis guru tidak dapat menjawab pertanyaan asli dengan memadai. Oleh karena itu, analisis data dilakukan ulang dengan tiga lulusan perguruan tinggi dengan gelar psikologi yang berasal dari Jawa, akrab dengan wilayah Sleman atau budaya Yogyakarta dan juga terbiasa dengan istilah psikologis yang digunakan oleh orang Jawa. Pada tahap kedua dari analisis data, metode kuantitatif deskriptif diterapkan untuk mengidentifikasi kategori luas dan kategori selektif untuk diringkas lebih lanjut ke dalam tema utama. Salah satu cara paling umum untuk mendeskripsikan variabel adalah dengan distribusi frekuensi. Berdasarkan pertanyaan terbuka yang diajukan kepada peserta penelitian, distribusi frekuensi akan dikembangkan untuk menampilkan persentase gagasan tertentu dalam tanggapan peserta. Kata kunci dan kategori luas, yang diproduksi 
oleh kelompok analis kedua ini dan telah menjawab pertanyaan-pertanyaan yang sesuai, adalah dasar untuk statistik deskriptif yang disajikan. Selanjutnya, berdasarkan tema kategori selektif tema akan dikembangkan untuk mengidentifikasi konstruk integritas dalam perspektif guru sekolah dasar di Indonesia.

\section{Hasil}

\section{Arti integritas}

Pengategorian jawaban responden dilakukan untuk mencari tahu mengapa integritas penting bagi subjek. Pertanyaan pertama adalah "Istilah integritas telah banyak digunakan untuk menggambarkan sifat orang baik, mengapa seseorang harus memiliki integritas?" Jawaban yang diberikan partisipan dapat dilihat pada Tabel 1.

Tabel 1

Makna Integritas (Kategori Luas)

\begin{tabular}{lc}
\hline \multicolumn{1}{c}{ Kategori } & Frekuensi \\
\hline Kualitas diri & $20.49 \%$ \\
Agar diterima secara sosial & $13.11 \%$ \\
Pemenuhan tugas & $12.30 \%$ \\
Kualitas hidup & $11.48 \%$ \\
Kontrol perilaku & $10.66 \%$ \\
Untuk menjadi teladan & $4.92 \%$ \\
Agar berhasil & $3.28 \%$ \\
Agar dipercaya & $3.28 \%$ \\
Tanggung jawab & $3.28 \%$ \\
Menghormati orang lain & $2.46 \%$ \\
Berfungsi baik dalam masyarakat & $1.64 \%$ \\
Mempengaruhi orang lain & $1.64 \%$ \\
Lain & $11.48 \%$ \\
\hline
\end{tabular}

Tabel 1 menggambarkan bahwa sebagian besar subjek percaya bahwa integritas berarti kualitas positif yang dimiliki oleh diri individu (20.49\%). Integritas juga berarti berperilaku dengan cara yang dapat diterima oleh standar sosial $(13.11 \%)$ atau untuk memenuhi tugas (12.3\%). Beberapa subjek menganggap integritas sebagai bagian dari kualitas hidup (11.48\%), mungkin sebagai perpanjangan kualitas diri. Tanggapan yang paling sedikit untuk arti integritas sebagai sarana untuk mempengaruhi orang lain (1.64\%) menunjukkan bahwa integritas lebih merupakan nilai intrinsik ke dalam diri terlepas dari dampaknya pada orang lain. Kategorikategori tersebut kemudian dapat disimpulkan sebagai berikut:

Tabel 2

Makna Integritas (Kategori Selektif)

\begin{tabular}{lc}
\hline \multicolumn{1}{c}{ Kategori } & Frequency \\
\hline Kualitas diri & $52.25 \%$ \\
Dapat dipercaya & $27.93 \%$ \\
Etos kerja & $19.82 \%$ \\
\hline
\end{tabular}

Dalam tabel kategori selektif (Tabel 2), dapat disimpulkan makna integritas sebagai karakteristik yang mewakili kualitas positif individu (52.25\%). Ini lebih menonjol daripada gagasan integritas untuk dipercaya oleh orang lain $(27.93 \%)$ atau sebagai etos kerja (19.82\%).

\section{Karakteristik integritas}

Kategori diciptakan r untuk
mengeksplorasi karakteristik integritas
berdasarkan sifat yang dirasakan oleh peserta
dengan memberi pertanyaan yaitu
"Karakteristik apa yang dimiliki oleh orang
yang memiliki integritas?"

Menurut guru SD yang menjadi partisipan, komposisi sifat yang diperlukan dalam individu untuk diidentifikasi sebagai orang yang berintegritas sebagian besar adalah tanggung jawab yang sangat tinggi (35.94\%), perilaku yang ramah (16.59\%) dan kerja keras yang diakui untuk mendapatkan posisinya di masyarakat (13.36\%) (Tabel 3). 
Tabel 3

Karakteristik yang Dianggap Sebagai Integritas (Kategori Luas)

\begin{tabular}{lc}
\hline \multicolumn{1}{c}{ Kategori } & Frekuensi \\
\hline Tanggung jawab & $35.94 \%$ \\
Ramah & $16.59 \%$ \\
Bekerja keras & $13.36 \%$ \\
Berpegang teguh pada prinsip & $9.91 \%$ \\
Kepemimpinan & $9.45 \%$ \\
\hline Religius & $3.23 \%$ \\
Kompeten & $2.53 \%$ \\
Berwawasan & $2.53 \%$ \\
Mampu mengendalikan emosi & $2.07 \%$ \\
Keterbukaan & $0.92 \%$ \\
Komunikatif & $0.92 \%$ \\
Lain & $2.53 \%$ \\
\hline
\end{tabular}

Tabel 4

Karakteristik yang Dianggap Sebagai Integritas (Kategori Selektif)

\begin{tabular}{lc}
\hline \multicolumn{1}{c}{ Kategori } & Frekuensi \\
\hline Karakter yang baik & $60.60 \%$ \\
Kecakapan & $24.65 \%$ \\
Komitmen kerja keras yang nyata & $14.75 \%$ \\
\hline
\end{tabular}

Sebagai simpulan, struktur karakteristik yang menyusun integritas adalah karakter baik yang diakui dimiliki oleh seseorang (60.60\%), menunjukkan kompetensi di beberapa area $(24.65 \%)$ serta berkomitmen dalam kerja keras dan menghasilkan hasil yang nyata juga dianggap sebagai semacam integritas (14.75\%). Karakter atau kebajikan yang baik dari seseorang dianggap sebagai aspek integritas yang lebih tinggi meskipun memiliki kompetensi atau pekerjaan yang sebenarnya. Selengkapnya dapat diliat di Tabel 4.

\section{Indikator perilaku integritas}

Untuk memperjelas indikator perilaku berintegritas yang diamati oleh partisipan, maka kategori dibuat berdasarkan jawaban partisipan atas pertanyaan berupa "Berikan contoh perilaku yang dianggap sebagai perilaku berintegritas!"

Tabel 5

Indikator Perilaku Berintegritas (Kategori Luas)

\begin{tabular}{lc}
\hline \multicolumn{1}{c}{ Kategori } & Frekuensi \\
\hline Humanis & $22.01 \%$ \\
Jujur & $15.31 \%$ \\
Kepemimpinan & $12.44 \%$ \\
Bertanggung jawab & $8.61 \%$ \\
Berjuang untuk yang lain & $7.18 \%$ \\
Disiplin tinggi & $6.70 \%$ \\
Memegang teguh prinsip & $6.70 \%$ \\
Pekerjaan nyata & $5.74 \%$ \\
Kemampuan kognitif & $5.26 \%$ \\
Dapat menjadi panutan & $5.26 \%$ \\
Keberanian & $1.44 \%$ \\
Lain & $2.39 \%$ \\
\hline
\end{tabular}

Dalam tabel kategori luas (Tabel 5), sisi kemanusiaan dalam sejumlah tindakan terbukti dianggap sebagai tanda-tanda integritas (22.01\%) selain jujur $(15.31 \%)$ dan menunjukkan kualitas kepemimpinan (12.44\%).

Tabel 6

Indikator Perilaku Berintegritas (Kategori Selektif)

\begin{tabular}{lc}
\hline \multicolumn{1}{c}{ Kategori } & Frekuensi \\
\hline Kebajikan & $54.55 \%$ \\
Kesesuaian & $21.53 \%$ \\
Kompetensi & $17.70 \%$ \\
Pekerjaan nyata & $6.22 \%$ \\
\hline
\end{tabular}

Pada akhirnya, kebajikan atau nilai positif yang ditunjukkan secara konsisten oleh tindakan seseorang akan dikonfirmasi sebagai indikator integritas terkuat (54.55\%). Kebajikan ini terdiri dari tindakan kemanusiaan, kejujuran, perilaku disiplin, bertanggung jawab, kepemimpinan, berprinsip, model peran, dan keberanian yang 
ditunjukkan oleh kategori luas. Sementara kesesuaian dengan norma dan aturan $(21.53 \%)$ masih dianggap sebagai dimensi perilaku integritas, menunjukkan kecakapan dalam berbagai bidang (17.70\%) juga dianggap indikator perilaku berintegritas (Tabel 6).

\section{Nilai/prinsip yang harus ditanamkan agar menjadi pribadi berintegritas}

Untuk mengidentifikasi nilai-nilai atau prinsip-prinsip integritas yang dirasakan harus ditanamkan pada para siswa, peserta menjawab pertanyaan "Sebutkan setidaknya tiga nilai atau prinsip yang Anda pikir harus dimiliki siswa Anda untuk tumbuh menjadi seseorang yang memiliki integritas tinggi?"

Tabel 7

Nilai-nilai yang Perlu Ditanamkan untuk Bertumbuh Berintegritas (Kategori Luas)

\begin{tabular}{lc}
\hline \multicolumn{1}{c}{ Kategori } & Frekuensi \\
\hline Kejujuran & $19.78 \%$ \\
Disiplin & $17.62 \%$ \\
Karakter yang baik & $10.84 \%$ \\
Tanggung jawab & $10.84 \%$ \\
Kerja keras & $6.78 \%$ \\
Adaptif & $6.50 \%$ \\
Religiusitas & $5.96 \%$ \\
Welas asih & $5.15 \%$ \\
Prinsip-prinsip baik & $4.34 \%$ \\
Cerdas & $3.25 \%$ \\
Hormat & $2.71 \%$ \\
Pengorbanan & $2.44 \%$ \\
Keberanian & $1.36 \%$ \\
Teladan & $1.36 \%$ \\
Lain & $1.08 \%$ \\
\hline
\end{tabular}

Empat prinsip muncul sebagai nilai-nilai kuat yang yang harus ditanamkan dalam diri anak-anak agar tumbuh menjadi pribadi berintegritas. Kejujuran adalah nilai yang paling dekat diidentifikasi sebagai nilai utama integritas (19.78\%). Disiplin dianggap sebagai nilai terbaik kedua (17.62\%) yang mencerminkan integritas, sementara karakter baik lainnya (10.84\%) dan rasa tanggung jawab yang baik (10.84\%) juga harus dimiliki pribadi berintegritas (Tabel 7).

Tabel 8

Nilai-nilai yang Perlu Ditanamkan untuk Bertumbuh Berintegritas (Kategori Selektif)

\begin{tabular}{lc}
\hline \multicolumn{1}{c}{ Kategori } & Frekuensi \\
\hline Nilai-nilai positif dalam diri sendiri & $38.90 \%$ \\
Disiplin diri & $33.97 \%$ \\
Nilai-nilai positif sikap pada orang lain & $23.84 \%$ \\
Kompetensi & $3.29 \%$ \\
\hline
\end{tabular}

Berdasarkan kategorisasi luas pada Tabel 8, tiga nilai muncul sebagai nilai-nilai yang diakui menumbuhkan pribadi berintegritas, yaitu: (1) nilai positif dalam individu seperti kejujuran, keberanian, welas asih, konsisten dalam prinsip dan karakter yang baik (38.9\%); (2) Disiplin diri terutama bertanggung jawab dan bekerja keras dalam menyelesaikan tugas dan (33.97\%); dan (3) Nilai positif dalam berperilaku terhadap orang lain dengan rasa hormat dan peduli (23.84\%) menunjukkan bahwa nilai sosial juga merupakan nilai integritas.

\section{Metode pembelajaran integritas}

Kategori dibuat untuk memahami bagaimana guru sekolah dasar akan mewariskan integritas kepada siswa mereka dengan bertanya kepada peserta yaitu "Bagaimana Anda akan mengembangkan nilai atau prinsip seperti itu di siswa Anda?"

Partisipan guru sekolah dasar yakin bahwa integritas harus dilatih melibatkan pengajaran nilai-nilai serta membuat siswa menerapkannya dalam praktek keseharian (34.78\%). Metode kedua adalah dengan memberikan contoh (29.81\%). Mengarahkan 
penerapan integritas dalam perilaku siswa $(11.18 \%)$ dan mengajarkan nilai-nilai dasar integritas $(10.56 \%)$ juga penting untuk mengembangkan integritas di antara para siswa pada usia dini (Tabel 9).

Tabel 9

Metode Pembelajaran Berintegritas (Kategori Luas)

\begin{tabular}{lc}
\hline \multicolumn{1}{c}{ Kategori } & Frekuensi \\
\hline Latihan dalam keseharian & $34.78 \%$ \\
Teladan melalui contoh perilaku & $29.81 \%$ \\
Arahan perilaku & $11.18 \%$ \\
Mengajarkan & $10.56 \%$ \\
Pengawasan perilaku & $5.59 \%$ \\
Menjelaskan tentang integritas & $4.97 \%$ \\
Hadiah dan hukuman & $1.86 \%$ \\
Lain & $1.24 \%$ \\
\hline
\end{tabular}

Tabel 10

Metode Pembelajaran Berintegritas (Kategori Selektif)

\begin{tabular}{lc}
\hline \multicolumn{1}{c}{ Kategori } & Frekuensi \\
\hline Latihan & $50.31 \%$ \\
Memberikan contoh & $29.81 \%$ \\
Arahan perilaku & $16.77 \%$ \\
Penguatan & $3.11 \%$ \\
\hline
\end{tabular}

Kategori luas memaparkan kepercayaan para guru bahwa pelatihan yang mengajarkan nilai-nilai dasar integritas adalah metode terbaik untuk meneruskan integritas $(50.31 \%)$. Memberikan contoh tindakan integritas bagi guru $(29.81 \%)$ serta mengawasi aktivitas siswa (16.77\%) juga merupakan sarana penting untuk mengajarkan integritas.

Kategori-kategori yang dihasilkan dari fase 1 dan 2 dari analisis data kemudian dirangkum menjadi tema-tema utama seperti yang ditunjukkan pada Tabel 11.

\section{Diskusi}

\section{Makna integritas}

Secara filosofis, tekad atau konsistensi dapat dianggap tidak memiliki hubungan dengan prinsip-prinsip moral. Jika definisi integritas digambarkan sebagai memiliki tekad, sifat-sifat ini dapat dimiliki oleh seseorang dengan karakter yang baik dan buruk. Seorang anggota Yakuza yang mempertahankan kesetiaan mereka kepada organisasi dalam berbagai kondisi yang parah juga dapat dipanggil untuk memiliki keberanian. Seorang pengacara yang menyembunyikan kebenaran untuk mempertahankan kemenangan bagi kliennya yang bersalah. Bauman (2011) membedakan antara integritas substantif yang berisi komitmen terhadap nilai-nilai moral dengan integritas formal yang tidak selalu berkomitmen terhadap nilai-nilai moral. Jadi, konsisten dan memegang prinsip seyogyanya juga disertai dengan nilai-nilai baik yang tidak berlawanan dengan standar moral. Para guru sekolah dasar yang menjadi partisipan setuju bahwa integritas adalah kualitas seorang individu yang memiliki integritas adalah memiliki nilai-nilai positif yang diyakini secara otentik dan didedikasikan dalam perilaku dan diakui sebagai orang yang dapat dipercaya yang menerapkan etos kerja yang mengagumkan dalam menyelesaikan tugas atau kewajibannya

Simpulan dari data penelitian tentang arti integritas sesuai dengan ide Peterson dan Seligman (2004) tentang integritas, terutama dua poin pertama dari kriteria: pola perilaku yang konsisten dengan nilai yang dianut, konsisten antara kata dan perbuatan, diakui memegang keyakinan moral, bahkan jika keyakinan itu tidak populer.

Data penelitian menunjukkan hanya sejumlah kecil peserta menekankan rasa hormat dan perhatian kepada orang lain (2.46\% pada Tabel 1 dan $2.71 \%$ pada Tabel 7) 


\section{KERANGKA KONSEPTUAL INTEGRITAS}

sebagai aspek integritas. Konsepsi ini menunjukkan perbedaan dengan poin ketiga dalam Peterson \& Seligman (2004) kriteria integritas yang mengharuskan memperlakukan orang lain dengan hati-hati, membantu mereka yang membutuhkan atau bisa disebut juga kepekaan terhadap kebutuhan orang lain.

\section{Karakteristik seseorang dengan integritas}

Ada tiga tema utama dalam tanggapan peserta penelitian untuk mengkarakterisasi fitur utama dari orang yang berintegritas:
1. Pegang kebajikan positif (jujur, bertanggung jawab, kualitas hidup, sesuai dengan standar moral);

2. Kompetensi untuk bertindak berdasarkan kebajikan (perilaku yang berfungsi secara sosial, perilaku yang dikendalikan, disiplin diri);

3. Tekad untuk memegang kebajikan (ketekunan, keyakinan, menyelesaikan tugas dan tugas).

Tabel 11

Tema dan Kategori Utama

\begin{tabular}{|c|c|c|}
\hline Tema & Kategori-kategori Utama & Bukti \\
\hline \multirow[t]{3}{*}{ Makna Integritas } & $\begin{array}{l}\text { Merupakan kualitas dari seseorang (disiplin diri, memegang prinsip } \\
\text { atau nilai yang baik, visi hidup, kualitas hidup) }\end{array}$ & Tabel 2 \\
\hline & Terpercaya (bertanggung jawab, jujur) & \\
\hline & Bagian utama etos kerja (menyelesaikan tugas dan tanggung jawab) & \\
\hline \multirow[t]{3}{*}{$\begin{array}{l}\text { Karakteristik seseorang } \\
\text { dengan integritas }\end{array}$} & $\begin{array}{l}\text { Memegang teguh kebajikan positif (jujur, bertanggung jawab, } \\
\text { kualitas hidup, sesuai dengan standar moral) }\end{array}$ & $\begin{array}{l}\text { Tabel } 1,4 \& \\
\text { Tabel } 5\end{array}$ \\
\hline & $\begin{array}{l}\text { Kompetensi untuk bertindak berdasarkan kebajikan (perilaku yang } \\
\text { menunjukkan keberfungsian sosial yang baik, perilaku yang } \\
\text { terkendali, disiplin diri) }\end{array}$ & Tabel3 \\
\hline & $\begin{array}{l}\text { Tekad untuk memegang teguh kebajikan (menyelesaikan tugas dan } \\
\text { tanggung jawab, ketekunan, kerja keras) }\end{array}$ & Tabel $3 \& 5$ \\
\hline \multirow[t]{2}{*}{ Tujuan memiliki integritas } & $\begin{array}{l}\text { Penyesuaian yang baik (adaptasi sosial yang baik dan menghargai } \\
\text { orang lain) }\end{array}$ & Tabel $3 \& 5$ \\
\hline & $\begin{array}{l}\text { Berfungsi dengan baik di masyarakat atau produktif (bekerja keras, } \\
\text { menyelesaikan tugas dan bertanggung jawab) }\end{array}$ & Tabel 1 \\
\hline \multirow{3}{*}{$\begin{array}{l}\text { Nilai-nilai yang harus } \\
\text { dikembangkan agar tumbuh } \\
\text { menjadi pribadi berintegritas }\end{array}$} & $\begin{array}{l}\text { Nilai-nilai positif (kejujuran, keberanian, welas asih, konsisten pada } \\
\text { prinsip dan karakter yang baik) }\end{array}$ & Tabel $7 \& 8$ \\
\hline & $\begin{array}{l}\text { Nilai positif untuk orang lain (Hormat pada orang lain, peduli, } \\
\text { mudah beradaptasi dalam lingkungan sosial) }\end{array}$ & \\
\hline & Disiplin & \\
\hline $\begin{array}{l}\text { Mengembangkan integritas } \\
\text { pada anak-anak }\end{array}$ & $\begin{array}{l}\text { Melatih dalam keseharian, memberi contoh teladan danmemberi } \\
\text { pengarahan }\end{array}$ & $\begin{array}{l}\text { Tabel } 9 \& \\
10\end{array}$ \\
\hline \multirow[t]{3}{*}{ Kompetensi dalam integritas } & $\begin{array}{l}\text { Memiliki nilai-nilai positif atau kebajikan (intrapersonal dan } \\
\text { interpersonal) }\end{array}$ & $\begin{array}{l}\text { Tabel } 1,4,5, \\
6 \& 8\end{array}$ \\
\hline & $\begin{array}{l}\text { Menggunakan sumber daya dengan tekun untuk mencapai sesuatu } \\
\text { (kerja keras, ketekunan) }\end{array}$ & Tabel $2 \& 3$ \\
\hline & Konsistensi dalam perilaku (disiplin, bertanggung jawab, berprinsip) & Tabel $1 \& 3$ \\
\hline
\end{tabular}


Tema-tema utama ini konsisten dengan karakteristik yang diperlukan dari orang integritas yang diakui oleh Ashford (2000) bahwa para agen memiliki pemahaman yang pasti tentang kewajiban moral mereka yang sebenarnya. Seseorang yang berintegritas juga harus memiliki tekad untuk membela penilaian moral mereka dalam sebuah komunitas (Calhoun, 1995).

\section{Pentingnya integritas}

Hasil utama penelitian mengenai pentingnya memiliki integritas adalah:

1. Penyesuaian yang sehat dalam masyarakat (misal, mudah bergaul, humanis);

2. Berfungsi baik atau produktif dalam masyarakat (yaitu berhasil meskipun ada hambatan, menyelesaikan tugas dan tugas wajib).

\section{Nilai-nilai yang tertanam dalam integritas}

Sebagian besar peserta penelitian setuju bahwa nilai-nilai positif tertentu yaitu kejujuran, disiplin atau konsistensi untuk dipegang oleh orang yang berintegritas. Nilainilai positif dapat diklasifikasikan menjadi dua kelompok besar:

1. Nilai-nilai positif dari diri sendiri yaitu kejujuran, keberanian, konsisten dalam prinsip dan karakter yang baik;

2. Nilai-nilai positif untuk orang lain yaitu menghormati orang lain, belas kasih, peduli, dapat beradaptasi dengan keadaan sosial.

\section{Kompetensi dalam integritas}

Data menunjukkan bahwa orang yang berintegritas memiliki keyakinan tertentu dalam nilai-nilai positif atau kebajikan (intrapersonal dan interpersonal), menyiratkan bahwa orang tersebut memiliki kecerdasan moral. Kecerdasan moral adalah memiliki pengetahuan tentang prinsip-prinsip moral dan menggunakan pengetahuan dalam mempertimbangkan atau bernalar moral (Barnard, Schurink \& De Beer, 2008).

Beberapa kompetensi yang harus dimiliki oleh seorang yang berintegritas antara lain adalah menggunakan sumber daya dengan tekun untuk mencapai sesuatu (yaitu kejujuran, kerja keras, ketekunan). Upaya sungguhsungguh untuk menerapkan nilai-nilai positif yang diyakini untuk memecahkan semua masalah yang dihadapi dalam kehidupan juga merupakan kompetensi yang diungkap oleh partisipan.Para partisipan juga menyebut mengenai konsistensi sebagai salah satu cirri integritas. Konsistensi individu (disiplin diri, bertanggung jawab, berprinsip) ditunjukkan dengan menerapkan nilai-nilai positif yang diyakini dan tidak goyah dalam menghadapi penghalang. Konsistensi seseorang juga harus berarti kesesuaian antara hasil yang diharapkan dan upaya nyata untuk mencapainya, konsisten antara pernyataan dan tindakannya.

\section{Pengembangan integritas}

Rupanya, sebagian besar guru sekolah dasar yakin bahwa siswa mereka belajar nilai dan praktik integritas dengan mengajar mereka dan dengan menunjukkan contoh. Namun, sebagai orang dewasa, para guru menemukan model peran inspiratif terutama dalam tokoh agama, orang tua mereka, dan pemimpin mereka (pemimpin bangsa dan lembaga). Dalam mempelajari perkembangan integritas, menjadi jelas bahwa perkembangan integritas guru sekolah dasar Indonesia sangat berakar pada latar belakang agama dan pendidikan keluarga mereka sebagaimana disarankan Barnard dkk. (2008). Mereka juga melihat figur kepemimpinan untuk karakteristik orang dengan integritas tinggi. Gagasan ini 
memunculkan kebutuhan figur pemimpin di pemerintahan dan institusi yang berkomitmen untuk menjadi figur integritas yang patut diteladani.

Pembahasan di atas, bila digambarkan dalam kerangka kerja konseptual adalah sebagai berikut:

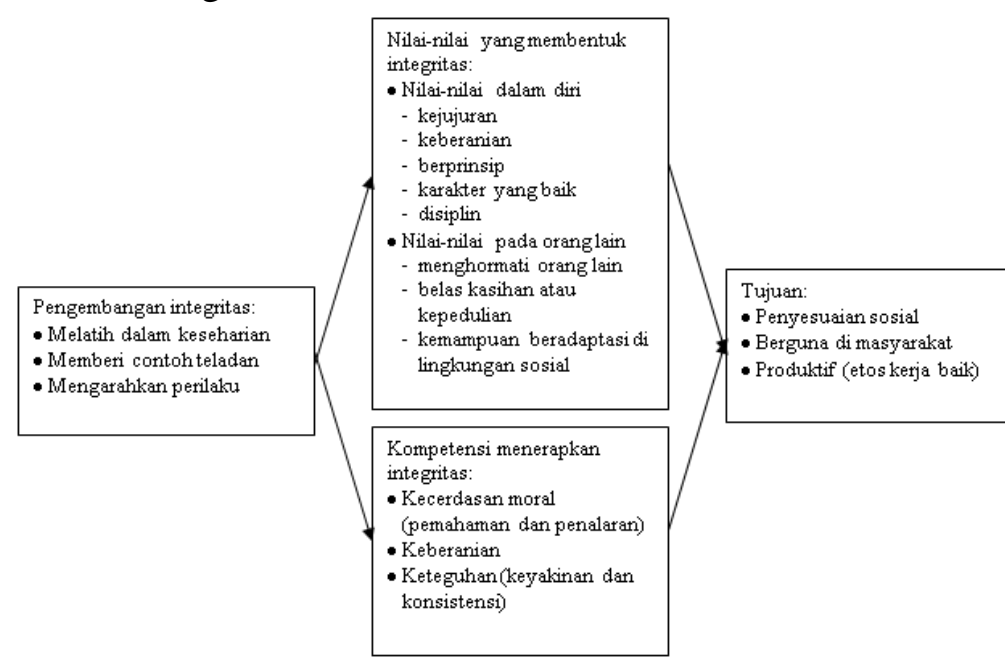

Gambar 1. Kerangka kerja konseptual Integritas menurut guru sekolah dasar

Kerangka kerja konseptual integritas menurut guru sekolah dasar di atas menunjukkan kesimpulan dari hasil penelitian yang menjawab pertanyaan-pertanyaan penelitian mengenai makna dan aspek integritas serta peran guru sekolah dasar dalam pengembangan integritas. Kerangka ini akan menjadi acuan dalam pengembangan teori lebih lanjut mengenai integritas dan memerlukan pembuktian lebih lanjut dengan pendekatan kuantitatif.

Selain konstruksi kerangka konseptual di atas, ada beberapa hasil penelitian yang layak untuk dibahas. Perhatian utama penelitipada hasil penelitian adalah persentase kecil yang mengkhawatirkan dari peserta yang menyebutkan keberanian (1.84\%) dan keadilan $(0.92 \%)$ sebagai karakteristik orang dengan integritas. Menurut Barnard dkk. (2008), kompetensi utama integritas mencakup adanya keberanian moral sebagai dorongan batin untuk bertindak dan berjuang untuk apa yang dipercayai dan menunjukkan prinsip dan nilai dengan tegas. Keadilan menjamin pemerataan dan non bias dalam pengambilan keputusan individu terutama yang melibatkan atau mempengaruhi orang lain. Kurangnya kombinasi keberanian moral dan rasa keadilan dapat menghambat penegakan keadilan moral di masyarakat. Hal ini menjelaskan banyak kasus di mana komunitas atau masyarakat Indonesia gagal membela keadilan publik meskipun masyarakat menang secara jumlah. Program komunitas untuk meningkatkan kesadaran akan keberanian moral dan rasa keadilan sangat diperlukan untuk melawan ketidakadilan atau korupsi yang dilakukan para elit negeri.

Data penelitian juga menunjukkan hanya sejumlah kecil peserta menekankan rasa hormat dan perhatian kepada orang lain (2.46\% pada Tabel 1 dan $2.71 \%$ pada Tabel 7) sebagai aspek integritas. Rupanya, para guru sekolah dasar Indonesia lebih percaya bahwa integritas lebih erat terkait dengan etos kerja atau profesionalisme daripada kebajikan yang berlaku untuk semua aspek kemanusiaan. Analisis data menunjukkan satu hal yang memprihatinkan, tampaknya rasa hormat dan perhatian kepada orang lain tidak berfungsi sebagai landasan kuat untuk membela prinsipprinsip moral. Integritas hanya dianggap sebagai sarana untuk menyesuaikan diri dengan masyarakat dan pencapaian di mata masyarakat. Namun, masih ada harapan karena tampaknya sejumlah kecil tanggapan menghargai upaya besar untuk orang lain (7.18\%) sebagai karakteristik orang dengan integritas. Pendidikan karakter harus menekankan rasa hormat dan kepedulian kepada orang lain sebagai fondasi utama dari semua standar integritas. 
Dalam mengembangkan integritas, melatih perilaku siswa dalam keseharian diakui sebagai cara yang paling mungkin dilakukan oleh para guru. Diperlukan ketekunan dan keteguhan hati dari pihak guru untuk terus menerus mengarahkan para siswa pada pengetahuan dan penerapan nilai-nilai integritas. Guru sendiri juga harus dapat menempatkan diri sebagai model peran yang diamante oleh siswa. Sebelum memberi contoh integritas yang baik, seorang guru harus menganut nilai-nilai integritas dan memperlihatkan usaha yang konsisten sesuai dengan konsep integritas yang akan diajarkan pada para siswa. Meskipun pendidikan secara luas telah dilihat sebagai struktur penting dalam memfasilitasi perilaku positif individu, figur pendidik sebagai panutan harus terusmenerus menjaga konsistensi perilaku dan diperlukan penguatan yang signifikan dari institusi terkait.

Penelitian ini mengonstruksi kerangka kerja konseptual integritas dari pandangan guru sekolah dasar Indonesia dan berfungsi sebagai dasar struktur konseptual yang perlu diperjelas lebih lanjut dengan analisis data kuantitatif seperti analisis data eksploratori dan konfirmasi. Konstruksi yang dihasilkan dari penelitian ini harus diperiksa secara menyeluruh untuk memastikan validitas konstruk dan interkoneksi di antara variabel yang membentuk konsep integritas. Salah satu tahap yang dapat dilalui untuk memastikan validitas konstruk dan interkonksi antar variabel adalah menggunakan jaringan nomologis yang dikembangkan oleh Lee Cronbach dan Paul Meehl pada tahun 1955. Hal ini dilakukan sebagai bagian dari upaya untuk mengembangkan standar untuk pengujian psikologis untuk konstruk integritas. Hal ini berarti untuk memberikan bukti bahwa pengukuran integritas yang akan dikembangkan memiliki validitas konstruk. Tahapan setelah membangun kerangka kerja teoritis ini adalah membangun kerangka kerja empiris untuk bagaimana Anda akan mengukurnya, dan spesifikasi hubungan antara dan di antara dua kerangka kerja penelitian.

Hasil penelitian ini masih ditarik dari sampel dalam jumlah kurang banyak mengingat luasnya pemaknaan integritas. Penelitian perlu dilakukan di berbagai lapisan masyarakat yang memiliki kepentingan relevan dengan konsep integritas misalnya peneliti di perguruan tinggi, pegawai pemerintahan atau pelaku bisnis di perusahaan. Dengan demikian konstruk ini dapat dibangun secara menyeluruh dan mempertimbangkan banyak sudut pandang.

Latar belakang budaya para peserta praktis homogen (Jawa Tengah) sehingga ada kebutuhan untuk memelajari konsep ini dalam latar belakang budaya yang berbeda. Indonesia terdiri dari banyak tradisi subbudaya dan kurang akurat menyimpulkan konsepsi luas tentang integritas hanya berdasarkan pada satu latar belakang budaya. Studi lebih lanjut harus mengeksplorasi integritas bangsa Indonesia dari warisan budaya yang beragam. Penelitian juga harus dilakukan untuk memasukkan ukuran sampel yang jauh lebih besar untuk memastikan representasi penduduk Indonesia dan untuk menjamin generalisasi yang valid dari kesimpulan penelitian.

Integritas sering dipandang sebagai urusan pribadi seseorang. Struktur dan proses sosial (misalnya keluarga, agama) serta sistem politik (misalnya pemerintah atau pemimpin) sesungguhnya dapat mempengaruhi integritas pribadi dan kurang memperoleh perhatian (Cox dkk., 2013). Idealnya, institusi yang membentuk kehidupan seseorang harus terstruktur dengan cara yang dapat memberi 
tempat terhormat bagi integritas. Jadi, penting untuk mendorong integritas tidak hanya di sekolah atau bisnis tetapi di semua struktur kehidupan. Sehingga diperlukan penelitian yang mencakup observasi sistem di lingkungan sosial dan institusi dalam penerapan integritas.

\section{Daftar Pustaka}

Ashford, E. (2000). Utilitarianism, integrity and partiality. The Journal of Philosophy, 97(8), 421-439. doi: https://doi.org/10.5840/jphil200097834

Barnard, A., Schurink, W., \& De Beer, M. (2008). A conceptual framework of integrity: empirical research. SA Journal of Industrial Psychology, 34(2), 40-49. https://hdl.handle.net/10520/EJC89154

Barret, C. (2003). Integrating qualitative and quantitative approaches: lessons from the pastoral risk management project. Dalam S. R. Kanbur (Ed.), $Q$ Squared: combining qualitative and quantitative methods of poverty appraisal (hal. 90-96). Hyberabad: Orient Blackswan.

Becker, T. E. (1998). Integrity in organizations: Beyond honesty and conscientiousness. Academy of Management Review, 23(1), 154-161. https://www.jstor.org/stable/259104

Becker, T. E. (2005). Development and validation of a situational judgment test of employee integrity. International Journal of Selection and Assessment, 13(3), 225-232. doi: https://doi.org/10.1111/j.14682389.2005.00319.x

Bigelow, J., \& Pargetter, R. (2007). Integrity and autonomy. American Philosophical Quarterly, 44(1), 39-49. https://www.jstor.org/stable/20464353

Calhoun, C. (1995). Standing for something. The Journal of Philosophy, 92(5), 235-260. doi: https://doi.org/10.2307/2940917

Cameron, K. S. (2003). Organisational virtuousness and performance. Dalam J. E. Dutton, \& R. E. Quinn (Eds.), Positive organisational scholarship: Foundations of a new discipline (hal. 4865). San Francisco: Berrett-Koehler.

Camic, P. M., Rhodes, J. E., \& Yardley, L. E. (2003). Qualitative research in psychology: Expanding perspectives in methodology and design. Washington, DC: American Psychological Association.

Craig, S. B., \& Gustafson, S. B. (1998). Perceived leader integrity scale: An instrument for assessing employee perceptions of integrity. The Leadership Quarterly, 9(2), 127-145. doi: http://dx.doi.org/10.1016/S10489843(98)90001-7

Cox, D., La Caze, M., \& Levine, M. (2013). Integrity. Dalam E. N. Zalta (Ed.), The Stanford Encyclopedia of Philosophy. https://plato.stanford.edu/cgibin/encyclopedia/archinfo.cgi?entry=int egrity

Cronbach, L. J., \& Meehl, P. E. (1955). Construct validity in psychological tests. Psychological Bulletin,52(4), 281-302. doi: http://dx.doi.org/10.1037/h0040957

Halfon, M. (1989). Integrity: Philosophical Inquiry. Philadelphia: Temple 
University Press.

Harter, S. (2002). Authenticity. Dalam C. R. Snyder, \& S. J. Lopez (Eds.), Handbook of Positive Psychology. New York: Oxford.

Kiel, F., \& Lennick, D. (2005). Moral Intelligence: Enhancing Business Performance and Leadership Success. Upper Saddle River, NJ: Wharton School Publishing.

Kaiser, R. B., \& Hogan, R. (2010). How to (and how not to) assess the integrity of managers. Consulting Psychology Journal: Practice and Research, 62(4), 216-234. doi: http://dx.doi.org/10.1037/a0022265

McFall, L. (1987). Integrity. Ethics, 98(1), 520. doi: https://doi.org/10.1086/292912

Schabracq, M. J. (2003). Everyday well-being and stress in work and organisations. Dalam M. J Schabracq, J. A. M. Winnubst, \& C. L. Cooper (Eds.), The Handbook of Work And Health Psychology (hal. 9-36). Chichester: John Wiley \& Sons Ltd.

Transparency International. (2018). Corruption Perception Index 2017. Diambil dari www.transparency.org/news/feature/cor ruption_perceptions_index_2017

Treviño, L. K., Brown, M., \& Hartman, L. P. (2003). A qualitative investigation of perceived executive ethical leadership: Perceptions from inside and outside the executive suite. Human relations, 56(1), 5-37. https://doi.org/10.1177/0018726703056 $\underline{001448}$ 